\title{
Art Education Phenomena in The School Environment (a case study of the application of art education in a school environment)
}

\author{
Arsan Shanie ${ }^{1 *}$ \\ ${ }^{1}$ Universitas Islam Negeri Walisongo Semarang, Indonesia \\ *e-mail: arsanshanie@walisongo.ac.id
}

\begin{abstract}
Art education exists to help transfer knowledge and attitudes to students and is not to be seen as mere leisure time. Writing this article aims to restore the function of art education to its original function. The method in this study using the Literature method. The results of the research are, first, art is the result of imitation of nature in the form of creativity, feeling and human intention or human ability to do something, in the form of an expression of the artist's activity process starting from physical activity that comes from human feelings and is beautiful so that it can move the human soul and feelings. Second, art education is not present to create students who are experts in the field of art but to foster aesthetic and artistic sensitivity to form critical, appreciative, and creative attitudes in students as a whole. Third, the right approach or method to find out that children have aesthetic experiences using an action-based approach. Fourth, the benefits of art education are as a means to instill aesthetic values, by means of art education students have aesthetic sensitivity. Fifth, the aim of Art Education is not to educate students to become artists.
\end{abstract}

Keywords:

Art Education; Penomena; School Environment.

\begin{abstract}
ABSTRAK
Pendidikan seni ada untuk membantu mentransfer pengetahuan dan sikap kepada siswa, bukan hanya sebagai pengisi waktu senggang saja. Penulisan artikel ini bertujuan mengembalikan fungsi pendidikan seni rupa ke fungsi aslinya. Metode dalam penelitian ini menggunakan metode Literatur. Hasil penelitian ini adalah, pertama, seni merupakan hasil peniruan alam berupa kreativitas, perasaan dan niat manusia atau kemampuan manusia untuk melakukan sesuatu, berupa ekspresi dari proses aktivitas seniman yang dimulai dari aktivitas fisik tersebut. Berasal dari perasaan manusia dan indah sehingga dapat menggerakan jiwa dan perasaan manusia. Kedua, pendidikan seni tidak hadir untuk menciptakan peserta didik yang ahli di bidang seni tetapi menumbuhkan kepekaan estetika dan kesenian untuk membentuk sikap kritis, apresiatif, dan kreatif pada peserta didik secara keseluruhan. Ketiga, pendekatan atau metode yang tepat untuk mengetahui bahwa
\end{abstract}


anak memiliki pengalaman estetik dengan menggunakan pendekatan berbasis tindakan. Keempat, manfaat pendidikan seni adalah sebagai sarana untuk menanamkan nilai-nilai estetika. Melalui pendidikan seni peserta didik mempunyai kepekaan estetika. Kelima, Pendidikan Seni bertujuan untuk tidak semata-mata mendidik siswa menjadi seniman.

Keywords:

Pendidikan Seni; Fenomena; Lingkungan Sekolah.

\section{Introduction}

The progress of the nation and the rapid development of technology require that people be highly educated. Education itself has an important meaning for humans. For the sake of survival, education is considered an absolute necessity that everyone, both young and old, need. Because education is a necessity, many people continue their education to a higher level. Through education, a person can learn about many things. Education is universal and is one of the ways science has declined in all countries of the world. In Indonesia, a lot of knowledge is taught in an educational program in every school education unit, starting from the elementary school level to the tertiary level.

Based on the Law of the Republic of Indonesia Number 2 of 1989 concerning the National Education System; Education is a conscious effort to prepare students through mentoring, teaching, and / or training activities for their future roles. Education according to Mead (Rohidi, 2011: 54) is divided into two main functions, namely preserving in one way, and on the other hand developing values, beliefs and knowledge according to the individual, social and cultural needs of its citizens, and the results are clearly reflected in the way of thinking, behaving or living, speaking or acting of those who are learners. Thus education can be seen as a social institution that involves interaction with a number of people with a system of roles and norms in an effort to meet educational needs as social needs. The function of this institution is to mobilize environmental resources for educational needs by directing the belief value system and knowledge that becomes its reference. In everyday life, the results of education will be present as the behavior of members of society which enables them to have the ability to play a role in accordance with the demands of the moral reasoning and aesthetics of the community concerned.

The first education generally takes place at home and takes place in a variety of situations. Education also takes place in the community, among peers, and takes place in a variety of settings that will shape behavior so that it can adapt to the social environment. School is a place to draw knowledge values and self-confidence that are seen positively by society and in an effort to face the future and the environment with challenges.

School is a place where the education process is formally designed with a strong curriculum and achievement goals. School education is education that does not only include children's learning activities at school but also includes activities in living a group life to form and develop a culture. Schools are educational institutions in which there are social institutions that are owned by the 
community. The function of this institution is to ensure that there is an exploration of knowledge that includes values and patterns of behavior from one generation to another so that it can be applied properly. School or institutional education does not only exist as formal education whose service is solely for the benefit of education but also contains various non-formal activities aimed at preserving the important cultural values of society and developing the abilities of students, both individually and in groups.

Education is also an effort made by humans in shaping humanistic values (Setyawan Deddy, 2020: 41)In this process, the education carried out by schools needs to be designed in such a way as to be in line with these goals. Starting from the curriculum which, among others, contains subject matter or subjects. The purpose of giving subjects is to develop or transport students towards maturity and maturity as individual, social and cultural humans. That is, through the education process in schools it is hoped that in the future students will be able to become independent individuals, able to also play a role in social life in accordance with applicable norms and have dignity as capable citizens of the nation.

In that context, art is given as subject matter in public schools with the term art education which is generally suitable. According to (Rohidi, 2011). Art education is education with art as the medium. This means that art education is part of education in public schools whose teaching and learning activities can spur students towards maturity as dignified human beings. However, in reality art education that takes place in the school environment is carried out only to cover empty subjects left by the teacher, by giving assignments such as free drawing. This fact is almost universal in general schools located in remote areas. The fact that art education is only underestimated and does not match its actual function. This article was created with the hope of opening the eyes so that schools know the true function of art education.

\section{Method}

This research uses a qualitative type research (Gunawan, 2013) It isstudies in which the findings are not obtained by statistical procedures or other forms of calculation. Trying to understand and interpret an event of human behavior interaction in a particular situation from the perspective of the researcher himself. Research that can produce information in the form of descriptive data and the results are a collection of several sources used as research material. This research method leads to literature study research. As already explained by (Nazir, 2011) that literature study is a data collection technique using studybooks, literature, notes and reports relating to the problem being solved. Meanwhile, according to (Sugiyono, 2011) literature studies or literature studies related to theoretical studies andOther references related to values, culture and norms that develop in the social situation under study, besides this research is very important in conducting research, this research cannot be separated from the literature. An important step in the study of literature is to determine the topic of research and to seek research theories that come from books, journals, magazines, research results and various appropriate sources. 
It can be concluded that the literature study systematically identifies theories, library findings and analyzes documents containing information related to the research topic. According toto (Arikunto, 2010) there There are three ways to process existing datawhich were compiled, namely: (a) Editing, namely re-examination of the data obtained, especially in terms of completeness, clarity of meaning, and harmony of meaning with one another. (b) Organizing, organizing the data obtained in accordance with the subject matter. The research findings can be in the form of further analysis of the results of data organizing using predetermined rules, theories and methods, so that certain conclusions are obtained which are the results of the answers to the problem formulation.

\section{Result and Discussion}

\section{Concept art}

According to (Sumadi, 2005) Art is a human spiritual activity that reflects reality (masculinity) in a work related to its form and content, having data to evoke certain experiences of the recipient. Yet according to (Sabatari, 2006) "Art is all kinds of beauty created by humans", according to this way of thinking art is a product of beauty, human efforts to create beauty that can bring pleasure. Art is also the human ability to make or do something; creates humans, not nature (Sudjoko, 2001: 53). According to the college art is Proficiency thanks to experiential learning, or observation; Art makes friends This example shows that art doesn't have to be an object. The art of negotiation, the art of seduction, the art of administration, the art of love and many more, including martial arts. (Sudjoko, 2001: 55). Thomas Munro (Rondhi, 2014) Also argues that art is a human skill in providing satisfying stimulation to aesthetic experiences. Art (Saputra et al., 2018) in the form of all human actions that arise from feelings and natural beauty, so as to move the human soul and feeling.

From some of the definitions of art described above, art is the result of imitation of nature with all its contents in the form of copyright, human taste and human intention or ability to do something, in the form of an expression of the artist's physical activity process. Activity to physical activity originates from human feelings and is beautiful so that it can move the human soul and feelings.

\section{Education and the benefits of art education}

Art education is an effort to consciously prepare students through mentoring, teaching, and / or training activities in order to master artistic abilities according to the role that must be played (Soehardjo, 2012: 13). There are two roles that need to be played, namely transmitting artistic skills and enabling art (Read, 1945 and Wickiser, 1974). The first role of art education is transferring artistic skills or often referred to as the concept of art in education. In this concept, art is something that needs to be preserved and passed on / passed down to future generations. This concept will give birth to a product, namely the artist and his work. The works of art that were handed down were also varied. There are carving, batik, sculpture, printmaking, and so on. Art devolution in this concept can be done through formal or non-formal education. Through formal education, this concept is commonly applied in vocational arts schools. Meanwhile, through non-formal education, this concept is usually applied at home (artist's family) or in art workshops / studios. The second role of art education is to activate art or what is often called the concept of education through art. In this concept, art is a means 
for educators to instill certain human values through artistic activities, both in the realm of appreciation and creation. For example, when a child is taught how to work with the pointilis technique, it does not aim to turn the student into a pointist artist. However, educators want to instill the value of perseverance and patience in children because to work pointilis requires caution, attention, and patience. Like any other activity, usually there are certain values as goals. The second concept that must be applied in public schools an art education teacher must be able to provide an aesthetic experience to students rather than creating art experts.

\section{The benefits of art education}

Basically, art education in schools is directed at fostering aesthetic and artistic sensitivity so as to form critical, appreciative and creative attitudes in students as a whole. This attitude will grow if a series of activities are carried out on students which include observation, assessment, and the growth of a sense of belonging through student involvement in all art activities in the classroom and or outside the classroom. Thus art education involves all forms of activity in the form of physical activities and a sense of beauty which is expressed in activities of expression, exploration, appreciation and creation through language, sound, movement and role (fine arts, music, dance, and theater). Each of them contains material in accordance with the field of art and activities in artistic ideas, art skills and respect related to the socio-cultural context of society. (Diknas, 2004: 3). From the above concept, it can be concluded that art education should be used as a means to instill aesthetic values, by means of art education students have aesthetic sensitivity.

\section{Art Education Goals}

The purpose of Fine Arts Education is to provide aesthetic experiences so that students are able to provide feedback assessments (criticism and suggestions) on a work of art according to the medium, train students' imagination, provide the maximum possible facilities for expression. their opinion. The purpose of art education is not to educate students to become artists, but to educate children to be creative. For example, learning art education is carried out in elementary schools, in this case art is a game activity, through games we can educate children and foster their creativity as early as possible. Thus it can be said that art can be used as an educational tool.

In general, fine arts education for education, especially in elementary schools, is: 1 . Art as a visual language for elementary school-age children in their lives is very close to works of art. It can almost be said that children's behavior is close to family activities; there is no day without art. It can be said that art is the needs of children in: expressing opinions, imagining, playing, learning. understand the forms that exist around the child, feel: joy, sadness, and a sense of religion. In the context of the art of expressing opinions, it appears when children sing or dance or draw pictures with or without a theme. The works of art they displayed were in accordance with the wishes of the time; when the child imagines the pleasure of being on the mother's swing, and the mother sings it while singing a lullaby for example. The memory will reappear in the form of a woman and a cloth. The phrase can also take the form of chanting together and imitating someone with a doll. But it can also be a formless picture, which starts from drawing a beautiful airplane with a distinctive child shape, 
then after a few minutes the picture is crossed out to cover the surface. The original plane image is no longer visible. This is where the expression of the enemy plane shooting down the ideal plane is here. Furthermore, Art Helps Mental Growth It turns out that the example above is the development of a symbol of form that occurs when a child wants to express a form that is thought, felt or imagined. These forms follow the development of the child's mental age. At one time the growth of the child's body was faster than the development of the mind. The mismatch of children's development also causes the development of images of children with other children to become normal, due to variations in children's images. This is in line with the development of reason in children. For children with different development, where the function of reason develops faster than expression, events also affect pictures.

\section{Approaches and methods that are able to determine the aesthetic experience of students}

One approach or method that is appropriate to know so that children gain aesthetic experiences, for example in learning the art of music, is to use action-based learning. approaching where according to Regelki (1981: 11-13) Learning in form action learning is a form of learning that refers to an activity (study by doing). In this context, students learn through active involvement in absorbing all the information conveyed by the teacher. Student involvement in music can only be done mentally or physically. This is one of the most appropriate methods of providing musical experiences to students.

Related to action learning in art from Jamalus music (1988: 22) states that learning music in schools must be done through musical experience. This means that every form of learning the art of music as an effort to achieve basic competencies that are determined in terms of competence, expression, and music creation must be carried out through integrated activities by including music activities as one of its components. These musical activities can be in the form of listening to music, responding to music with rhythmic movements, singing, reading musical notations, playing musical instruments, and creating music. Action-based learning objectives which is done in schools is none other than through the appreciation of learning, expression and musical recreation that will be delivered by students creativity to students, develop attitudes, aesthetics and provide aesthetic experiences for students.

\section{Conlusions}

Art education exists not to create students who are experts in the arts but for fostering aesthetic and artistic sensitivity so as to form critical, appreciative and creative attitudes within students as a whole. This attitude will grow, if a series of activities are carried out on students which include observation, assessment, and the growth of a sense of belonging through student involvement in all art activities in the classroom and / or outside the classroom which involve all physical forms. activities and a sense of beauty are expressed in the activities of expression, exploration, appreciation, and creation through the language of form, sound, motion and role (fine arts, music, dance and acting).The right approach or method to find out that children get aesthetic experiences in learning the art of music is by using an action-based learning approach. Action-based learning objectives carried out in schools through learning appreciation, expression and music creation to build student creativity, develop attitudes, aesthetics and provide aesthetic experiences for students. The results of 
this study also show that the assessment in art education carried out in schools looks more at the process carried out by students. Art education is present in the middle The hustle and bustle of national development and free association, hopefully they will be able to carry out their roles as they should, become one of the tools that by learning art education produces students and students who have character, dignity and culture and have aesthetic experiences so that educational goals can run as desired.

\section{References}

Arikunto, S. (2010). Eltian Method. Jakarta: Rineka Cipta.

Couto, Nasbahry. (2012). Understanding Art Throughout the Ages and Some Aspects that Need to be Understood. Downloaded 22 June 2015 from http // nasbahrygallearyedu. Blogspot.com

Diknas. 2004. Application of Performance appraisal in Fine Arts Assessment. Jakarta: Ministry of Education

Gunawan, I. (2013). Qualitative research methods. Jakarta: Earth Literacy, 143.

Jamalus. 1988. Music Learning through Music Experience. Jakarta: Director General of the Ministry of Education

Nazir, M. (2011). Research Methods, Seventh Printing. Bogor: Indonesian ghalia publishers.

Regelski, TA 1981. General Music Teaching. London: Colllierv Macmilan Publishers

Rohidi, TR (2011). Art research methodology. Semarang: Cipta Prima Nusantara, 75, 116-121.

Rondhi, M. (2014). The Function of Art for Human Life: Theortic Study. Imagination: ArtJournal, 7 (2), 115-28.

Setyawan, Dedy Strengthening National Identity Through Learning Arts Education Based on Eastern Culture.Harmonia: Journal of Art Research and Education 20 (1) (2020), 39-46.Available online at http://journal.unnes.ac.id/nju/index.php/harmonia DOI: http://dx.doi.org/10.15294/harmonia.v20i1.21711

Sabatari, W. (2006). ART: BETWEEN FORM AND CONTENT. Imaginary: Journal of Arts and Arts Education, 4 (2).

Saputra, YA, Mauliani, L., \& Ismoyo, AC (2018). JAVA ART MUSEUM DESIGN APPROACH. PROTOTYPE JOURNAL ARCHITECTURE, 1 (2), 73-78.

Sugiyono, P. (2011). Qualitative quantitative research methodology and R\&D. Alpabeta, Bandung.

Sumadi, S. (2005). ACHDIAT K. MIHARDJA'S DEFINITION OF ARTS AND ITS APPLICATION IN ARTS CRAFTS. Ornaments of the ISI Surakarta Art Craft journal, 2 (1).

Sudjoko. (2001). Introduction to fine arts. Bandung: Directorate General of National Education 